\title{
The Influence of Internet on Gadget on the Development of Children's Social and Emotional Development
}

\author{
Kamtini, H.Wardi, D.Maya, H.P.Tambunan \\ \{kamtini01@unimed.ac.id\} \\ Faculty of Education, Medan State University, Medan, North Sumatra, Indonesia
}

\begin{abstract}
The child is a future investment that needs to be stimulated its development from an early age. Brain cells that possessed by children from birth will not be able to develop optimally if not given proper stimulus and support for its development. Children are very sensitive to human's acts. Children will be able to mimic or follow everything he/she saw without studying it. At times the media gadget is now very popular among the public, including children. In other words, the gadget isn't harmful if it's introduced to the children in only fleeting or for educational purposes. However, nowadays gadget is one of the media that parents make to calm child so they won't disturb their parents' work. It would have been very sad for the children of the world in terms of social, they will tend to be more subdued and prefer to be alone in doing everything. In terms of the emotion of the child will be more like getting angry and sometimes want to cry or whine when his wish was not fulfilled. They reasoned that action is more secure and easy to supervise the activities of the children. But they haven't thought of the influence of media on the children's' development of the habit of playing gadget. A lot of the negative effects that will arise among them: will be difficult to socialize, slow in development of motoric, and a significant change in behavior. So, it is very important the role of parents to supervise, control and pay attention to all activities of the child.
\end{abstract}

Keywords: Gadget, negative impact, the role of parents.

\section{Introduction}

Technology is currently popular among the public. The technology offers a lot of variety of human needs in the field of information and communication especially internet. An example is: in fact, for mothers, technology highly sought, not just to look for food to cook but also a place to buy or sell goods or objects that needed. For adolescents not to be outdone, it's for pursuing the technology not just to find information, adding insights but also to communicate with others.

Then, what about the children? Children are human beings who should still be experiencing growth and development to reach the adult stage. This development should be in accordance with his age, playing with friends, communicating with parents and his teacher and peers. But in fact, in modern times, the kids are only interested in the technology world. Why? These will be described in this paper. The problem formulation of this paper is as follows: what causes that make a child addicted to technology? What is the influence of technology on the development of children's social and emotional development? What are the factors that 
make children more interested in technology? How about the solution that can be applied? As for the purpose is to solve the problem of child who is addicted to gadgets.

\subsection{Technology}

Technology is an advanced means of communication that currently got a lot of humans' attention. Not just among adults but also among children. In technology it is divided from some parts i.e. television, radio, mobile and the internet. And currently the most developed is the internet. The Internet is a whole series of connected computer networks using the global system of standard Transmission Control Protocol/Internet Protocol Suite (TCP/IP) Packet Exchange Protocol (packet-switching communication protocol) to serve billions of users around the world. A large number of Internet users and still growing, has been realized the Internet culture. The Internet also has great influence over science, and world views. The development of the Internet has also influenced the development of the economy. A wide range of buying and selling that previously could only be done by way of face-to-face (and some very small by mail or phone), it is now very easy and often done over the Internet.

\subsection{The Meaning and History of Gadget}

Gadget is a term in the language of the United Kingdom that defines a small electronic device with a variety of special functions. Gadgets (Indonesian Language: Acang) is a term originating from the United Kingdom to refer to a device or instrument that has a specific purpose and practical functions that are useful and commonly given to something new. Gadgets in a general sense is considered as an electronic device that has a specific function on each device. For example: computers, mobile phones, games and more. The gadget has functions and benefits that corresponds to its users. Functions and benefits of gadgets in General include:

a. Communication

Science is more extensive and advanced. If ancient humans communicate via inner, then developed through writing that is sent through the post. Now the time of the era of globalization a human can communicate easily, fast, practical and more efficient by using mobile phone.

b. Social

The gadget has many features and applications are right for us to be able to share the news, and stories. So with such utilization can add friends and distant relatives in a relationship without having to use a relatively long time to share.

\section{c. Education}

Along with the development of the times, now studying not only focused with the book, but through the gadgets we can access a variety of science we need. About education, politics, public, religious and science, without having to bother to go to the library that may be far to reach.

\subsection{The Development of the Internet inthe Present}

In the current era of internet, it takes a website in support of the business of this virtual world. We know that with the internet then everything feels not limited between space and time. All dimensions are exceeded by the media the name of a website and the internet.

The development of the internet in Indonesia is very helpful in the development of every dimension of life in the world. Already now, we should optimize the potential of the internet 
to promote the nation and the State. Make development of the internet in Indonesia. Let us be positive internet users.

The Impact of the Internet Positive impact In line with the times, the progress of internet technology is also increasingly going forward. The Internet can make a positive impact for users such as: The Internet as a communication medium, is a function of the internet's most widely used where every internet user can communicate with other users from around the world and the Media to search for information or data, the rapid development of the internet, making it as one important source of information and accurate.

The Negative Impact the Internet is a computer network that connects internationally and spread all over the world. This network includes millions of aircraft computers connected to each other by making use of the telephone network (either wired or electromagnetic waves). A network of millions of computers allows a variety of applications implemented between computers in a network the internet-enabled software and hardware needed. Not only a positive impact but the internet is also one of which has a negative impact, namely: Nasty site: not just open a very nasty sites can damage the morals of the young generation (even older). The perpetrator can be very irresponsible and very easy to simultaneously be the culprit, by uploading or upload a photo or porn video via internet.

\subsection{Early Childhood}

Early childhood is defined as a group of children who are in the process of growth and development that is unique. They have a pattern of growth and development of the specialized according to the level of growth and development (Mansur, 2005). Characteristics of early childhood Kartini Kartono in Strain Marsudi (2006:6) characteristics of early childhood as follows:

(1) Egocentric is naïve Child looked at the outside world from his view of his own, in accordance with knowledge and his own understanding, restricted by the feelings and his thoughts are still narrow. Then the child is not yet able to understand the true meaning of an event and haven't been able to put himself into the lives of others.

(2) Primitive social relationship. Social Relationships which are the result of a primitive nature naïve egocentric. This trait is marked by the life of children who have not been able to separate between the social environments of the situation himself. Children at this time only have interest in the objects or events in accordance with his fantasies of power. Children begin to build his world with fantasy and desires of its own.

(3) Physical and spiritual Unity which barely separated Children not yet able to tell the difference between a world flesh and spirit. The contents of the outwardly and spirit is still a unified whole. Children imagination against something issued or given for free, spontaneous and honest both in facial, behavior or pretending, children express it openly because it does not teach or familiarize the child not to be honest.

(4) Attitude of life Child being physiognomic against the world, it means the children directly provide the attributes or properties of outward nature of concrete, tangible or of what imaginable. This condition is caused due to the child's understanding of what faces are still fused (totalitarian) between the physical and the spiritual. Children not yet able to distinguish between living and inanimate objects. Everything around him is considered to have a soul that is a living creature that has a physical and spiritual at the same time, like himself. Children are the next generation of the nation, so its presence is so eagerly anticipated by every human being, whether it's in a family environment, society, and Government. Childhood is a time of gold that cannot happen again, time sensitive and the development of all aspects of child development, 
which would later become the basis for further development. However, the ability of the child to grow and develop cannot attend. There are processes or stages that have to be gone through, which needed a stimulus from the environment to support its development optimally.

\subsection{The Child's Social and Emotional Development a) Understanding Emotions}

Emotion is a complex condition, may be feeling/thoughts that marked by the biological changes that arise from the behavior of a person. According to experts, the sense of emotions:

(1) According to Goleman (1995:411) "refers to a feeling of emotions or thoughts, a biological and psychological state as well as a series of tendencies to act."

(2) According to Syamsuddin (1990:69) expressed his "emotion is a complex atmosphere and soul or appear before or after the occurrence of a behavior." The function and role of emotions on child development are:

a. It's a form of communication.

b. Emotion plays a role in influencing the personality and adaptability of the child with his social environment.

c. Emotions can affect the psychological climate of the environment.

d. The same behavior and shown repeatedly can become a habit.

e. Tension of emotions that children have can inhibit or interfere with the child's mental and motor activity.

\section{b) Understanding Social Development}

According to experts the notion of social development:

(1) According to Plato, is potentially man is born as social beings.

(2) Fly $(1995: 105)$ revealed a "Socialization is the process of learning to be social creatures.

(3) According to Loree (1970:86) "Socialization is a process where the individual (child) coached her sensitivity towards the stimulation of social stimulationespecially the pressures and demands of life and learning to get along with to behave like others in his social environment.

(4) According to Muhibin (1999:35) said that social development is the process of establishment of the persons in the community.

(5) According to Hurlock (1978:250) That social development is gaining the ability to behave accordingly with the social demands. "Socializing is the ability to behave in accordance with the norms of social expectations or values".

\section{c) Characteristics and Characteristics Of Social Behavior}

In the social development of children, there are several characteristics in each period, the characteristics of such traits is -

1) Baby Period

Age 1-2 months, children have not been able to bring up the object and objects. Age 3-4 months, already strong eye look at people or objects, smile with another baby.

Age 5-9 months, respond differently to a friendly voice or not, sometimes aggressively, holding, looking at, follow the voice and mannerisms.

The age of 12 months, to know the restrictions. The age of 24 months, children are already helping to do simple activities 
2) The Period of Pre School

As for the traits - preschool socialization characteristics are as follows:

a. to make social contact with people outside his home

b. is known by the term pregang age

c. relationship with adult

d. relationship with peers

e. 3-4 years started playing together.

\section{Methodology}

\subsection{Withdrawal from the Social Environment}

The result of the addiction of gadgets the child will feel more comfortable surfing internet and will finally pull himself from the social environment. It is very influential, because children cannot socialize with her friends to another. Social just in terms of the emotion of the child will also be short-tempered if he disturbed when playing internet chat or play by other people.

\subsection{Not Easy to Get Along}

If the child is always adapting to the gadget then it will be difficult to get along even joined with others. The bigger impact is when children are in place of many children around, he will be more likely to be alone. Children will be alienated from the other kids.

\section{Result and Discussion}

As we know, the gadget is very influential in the daily life of human beings. While this is not the only adult, children also get involved in the development of the internet today. As it has been presented with the social and emotional development of the child should develop in accordance with the age ranging from interacting with his parents to communicate with the people around him. If the internet is constantly being the center of attention of the current child what are its effects on the social and emotional development. At present most parents are too preoccupied with the world of work, by reason of wanting to send her son, wanted his son to get an education, and extended to the growth of his son. With the busyness of parenting sometimes parents feel compromised if his work combined with the activities of the children, for example children asked to play along. For the sake of convenience of parents working freely sometimes parents made children play mobile phone for example YouTube or games. In fact, it can impact better if parents provide cognitive aspects that make the site or knowledge that children gain. But sometimes parents forget that if too often give and keep on the internet that always accompany the child with no idea can open unwanted sites. Let alone if the child be left alone. It is so influential on a child's emotions are not only social but on the emotion of the child. Here are some of the impact of the gadgets on the development of children's social and emotional. 


\subsection{Influencing Mental Health}

It's mentally very disturbed if the child is too focused on the internet. Because the child's emotions will not be controlled. When being bullied children are going to be angry and when their Cell phone is not taken or given the child would cry will even rebellious. With an already excessive addiction when prohibited mental child will be severely disrupted. The child will more easily upset and crying without reason because of early children only know the internet and when in an environment with other children will feel foreign.

Children who do not yet know the internet friendlier, easier to smile, it's easier to socialize and have a lot of friends. The children look more cheerful and uplifting in conducting all activities especially in group activities. Meanwhile, children who are already addicted to the internet, children tend to look crankier, crying easily, like himself and silent sector in places such as when her friend playing outside the classroom children tend to be in the class play alone. Of his emotions visible when notified or given the child sometimes want advice glare her eyes and whining also won't obey. And when her parents come children tend to directly pull the bags direct take of his mother and his mother's mobile phone from inside the bags and leave the classroom directly without farewell. When her mother forbade or hide mobile from the child, the child tends to cry and shout, sometimes threatening children don't want to go home if his mother doesn't give mobile. Solution in treating children who have influenced technology in terms of which negative have been presented below:

(1) Parents should take the time to the child and parent is also not allowed to use mobile phones when together.

(2) Parents should be more often go to the recreational areas that can attract the attention of children. Bring him to the book store and choose an interesting book by children.

(3) For teachers, teachers can give special attention to the child, such as: more often invite them to communicate and invites children to play games that are favored by children. Teachers can also invite children to be more active in group activities, for example: teachers are more likely to ask for the opinion of the child for the results of their cooperation and solve problems together.

\section{Conclusion}

Children are very sensitive to human development. Children will be able to mimic or follow everything he saw without studying it. In the era of internet media is now very popular among the public, not left behind are children. In other words, the internet does no harm to be introduced to the children if only fleeting or for educational purposes. However, nowadays internet media is one of the parents that usually use to make child calm and not so they won't interfere with parents in work. It would have been very sad for the world. Because the internet greatly affects social and emotional of children. In terms of social children tend to be more reserved and prefers to be alone in doing everything. In terms of the emotion of the child will be more like the angry and sometimes want to cry or whine when his wish was not fulfilled. We as adults should understand that it takes a child is not a chattel which although can satisfy the child but social and his emotions is disturbed, the child should require someone who can make him happy and cheerful in doing in all things. Children should play freely, explore her into a world that is supposed to be owned by early childhood. More parents should take the time for the child. Since it's parents that introduce children to the outside world to a good environment for the development of the child and to the world that make the children 
understand that it's not just her who exist but many friends or anyone else who can be the proximity to corporate.

\section{References}

[1] Anonim (2016) Pengertian dan sejarah Gedget, Accesed Oct 15, 2017, $<$ https://www.klikoffice.co.id/blog?journal_blog_post_id=68>.

[2] Anonim (2018) 10 Dampak Internet Terhadap Perkembangan Mental Pelajar, Accessed $<$ https://dosenpsikologi.com/dampak-internet-terhadap-perkembangan-mental-pelajar>.

[3] Bertens, K. (2004) Etika. Jakarta: Gramedia Pustaka Utama.

[4] Jonathan, et al. (2015) Perancangan Board Game Mengenai Bahaya Radiasi Gadget Terhadap Anak. Surabaya: Universitas Kristen Pertra Surabaya.

[5] Juwariyah, S. (2014) Pengaruh Media Sosial Pada Anak Usia Dini, Accessed $<$ https://juwariyahsiti.wordpress.com/2014/11/24/pengaruh-media-sosial-pada-anak-usiadini/>.

[6] Kemdinas (2012) Pedoman Pendidikan Karakter Pada Pendidikan Anak Usia Dini. Jakarta: Kementrian Pendidikan Nasional.

[7] Kumia, Y. (2012) Perkembangan Nilai-Nilai Moral dan Agama Bagi Anak Taman KanakKana. Bandung: PPPTK TK dan PLB.

[8] PAUD Jateng (2015) Perkembangan Sosial Emosional Anak Usia Dini (PAUD), Accessed $<$ https://www.paud.id/2015/09/perkembangan-sosial-emosional-anak-usia-dini.html>. 